\title{
Nuclear up regulation of the BRCA1-associated ubiquitinase BAP1 is associated with tumor aggressiveness in prostate cancers lacking the TMPRSS2:ERG fusion
}

\author{
Stefan Steurer ${ }^{1, *}$, Lara Schwemmer ${ }^{1, *}$, Claudia Hube-Magg $^{1}$, Franziska Büscheck', \\ Doris HöfImayer ${ }^{1}$, Maria Christina Tsourlakis' ${ }^{1}$, Till S. Clauditz' ${ }^{1}$, Andreas M. Luebke ${ }^{1}$, \\ Ronald Simon', Guido Sauter ${ }^{1}$, Jakob Izbicki ${ }^{2}$, Cornelia Schroeder ${ }^{2}$, Thorsten \\ Schlomm ${ }^{4}$, Hartwig Huland ${ }^{3}$, Hans Heinzer ${ }^{3}$, Alexander Haese $^{3}$, Markus Graefen $^{3}$, \\ Cosima Göbel ${ }^{1}$, Sören Weidemann', Patrick Lebok', David Dum¹, Christoph Fraune', \\ Sarah Minner ${ }^{1}$ and Jan Meiners ${ }^{2}$
}

\footnotetext{
${ }^{1}$ Institute of Pathology, University Medical Center Hamburg-Eppendorf, 20246 Hamburg, Germany

${ }^{2}$ General, Visceral and Thoracic Surgery Department and Clinic, University Medical Center Hamburg-Eppendorf, 20246 Hamburg, Germany

${ }^{3}$ Martini-Clinic, Prostate Cancer Center, University Medical Center Hamburg-Eppendorf, 20246 Hamburg, Germany

${ }^{4}$ Department of Urology, Charité - Universitätsmedizin Berlin, 10117 Berlin, Germany

*These authors contributed equally to this work

Correspondence to: Ronald Simon, email: r.simon@uke.de

Keywords: BAP1; prostate cancer; prognosis; immunohistochemistry

Received: June 27, $2019 \quad$ Accepted: September 24, $2019 \quad$ Published: December 24, 2019

Copyright: Steurer et al. This is an open-access article distributed under the terms of the Creative Commons Attribution License 3.0 (CC BY 3.0), which permits unrestricted use, distribution, and reproduction in any medium, provided the original author and source are credited.
}

\section{ABSTRACT}

Loss of the putative tumor suppressor BAP1 is a candidate biomarker for adverse prognosis in many cancer types, but conversely for improved survival in others. Studies on the expression and prognostic role of BAP1 in prostate cancer are currently lacking. We used a tissue microarray of 17,747 individual prostate cancer samples linked with comprehensive pathological, clinical and molecular data and studied the immunohistochemical expression of BAP1. BAP1 expression was typically up regulated in cancers as compared to adjacent normal prostatic glands. In 15,857 cancers, BAP1 staining was weak in $3.3 \%$, moderate in $41.6 \%$ and strong in $17.4 \%$. Strong BAP1 staining was associated with advanced tumor stage $(p<0.0001)$, high classical and quantitative Gleason grade $(p<0.0001)$, lymph node metastasis $(p<0.0001)$, a positive surgical margin $(p=0.0019)$ and early biochemical recurrence $(p<0.0001)$. BAP1 expression was linked to ERG-fusion type cancers, with strong BAP1 staining in 12\% of ERG-negative, but $30 \%$ of ERG-positive cancers $(p<0.0001)$. Subset analyses in 5,415 cancers with and 4,217 cancers without TMPRSS2:ERG fusion revealed that these associations with tumor phenotype and patient outcome were largely driven by the subset of ERG-negative tumors. Multivariate analysis revealed that the prognostic impact was independent of established prognostic features in ERG negative $p<0.001$ ) but not in ERG positive cancers. BAP1 expression was further linked to androgen receptor (AR) expression: Only $2 \%$ of AR-negative, but $33 \%$ of strongly AR expressing cancers had strong BAP1 expression $(p<0.0001)$. In conclusion, this study shows that BAP1 up regulation is linked to prostate cancer progression and aggressiveness. 


\section{INTRODUCTION}

Prostate cancer $(\mathrm{PCa})$ is the most diagnosed cancer among males in Western societies [1]. At this point, established prognosticators include histological analysis of biopsies to determine Gleason score and tumor extent, prostate-specific antigen (PSA) and clinical stage. However, current diagnostic analysis still proves prone to inaccuracies that could be reduced by finding a reliable and clinically applicable molecular marker. This could spare patients with otherwise harmless tumors the negative effects of treatment (e.g. incontinence and erectile dysfunction), and identify those patients with aggressive disease for whom the benefits of treatment outweigh its harm [2].
BRCA-1-associated Protein 1 (BAP1) is a nuclear deubiquitinase targeting histone modifying protein complexes that was originally named after its interaction with the E3 ubiquitin-protein ligase breastcancer type 1 susceptibility protein (BRCA1) $[3,4]$. Subsequent research revealed that BAP1 regulates many cellular pathways that are relevant for cell cycle control, cellular differentiation, gluconeogenesis, DNA damage response and apoptosis [5-7]. Al-though the mechanisms of action of BAP1 are still not fully understood, it is believed that one important function is the regulation of transcriptional silencing at the sites of DNA double-strand breakage repair [6]. BAP1 has long been considered a tumor suppressor. Mutation, genomic deletion of its locus at $3 \mathrm{p} 21$ or loss of BAP1

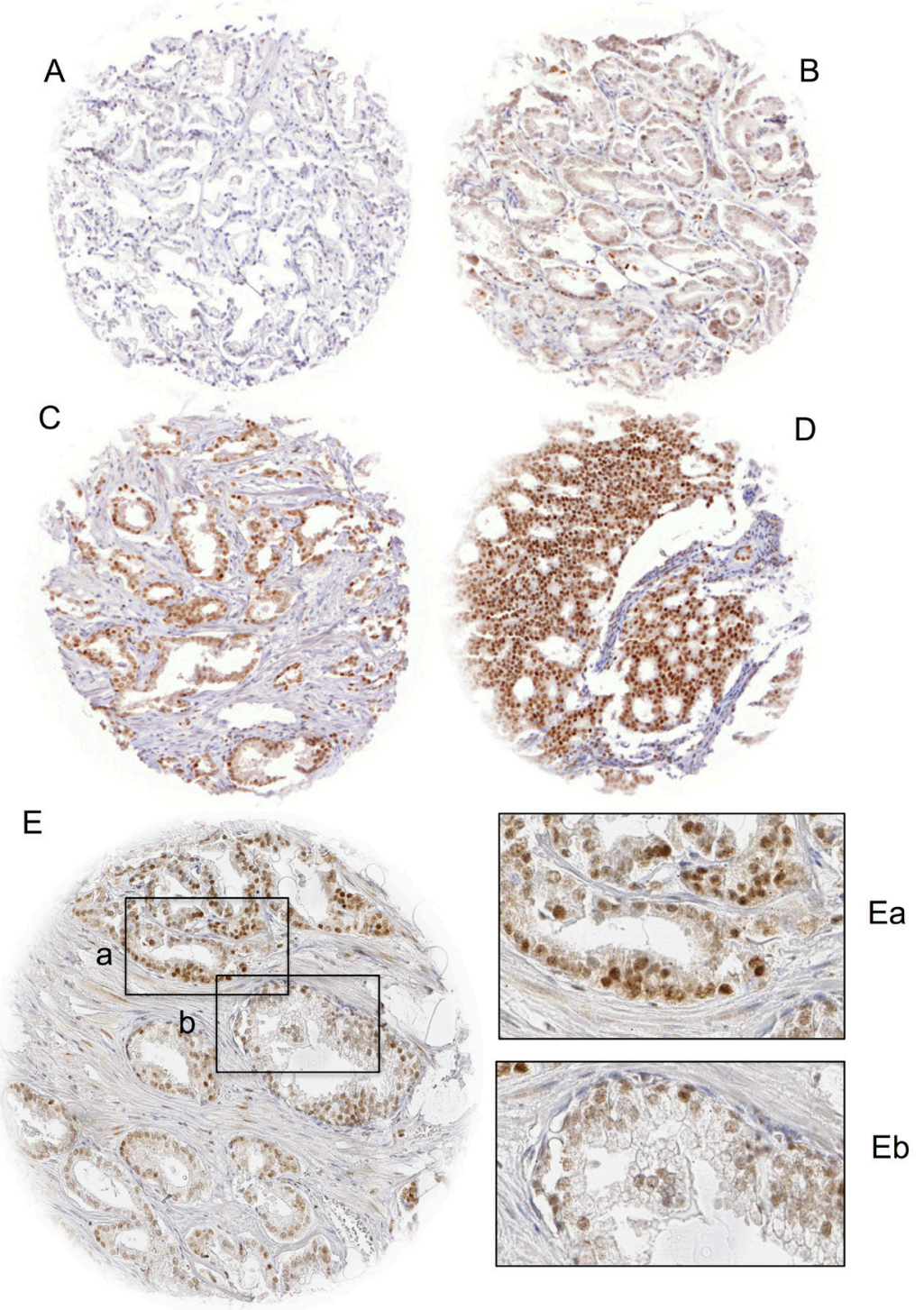

Figure 1: Examples of (A) negative, (B) weak, (C) moderate and (D) strong BAP1 staining in prostate cancer and (E) BAP1 staining of cancerous (Ea) and normal (Eb) prostate glands in the same TMA spot. Spot size is $0.6 \mathrm{~mm}$ at 100x (inset 400x) magnification. 
expression has been reported from various tumor types such as non-small cell lung cancer [8,9], renal cell carcinoma [10-12], gall bladder cancer [13], mesothelioma [14, 15] and uveal melanoma [16-18], and has been linked to poor prognosis in most of them $[13,17,19]$. In addition, inactivating germline mutations result in the BAP1 tumor predisposition syndrome, associated with a high risk of tumor development [20, 21]. However, the tumor-associated functions of BAP1 may be more complex than previously thought as some studies suggest a cancer-promoting role. For example, BAP1 loss or germline mutations have been linked to prolonged survival in malignant pleural mesothelioma $[11,12,22,23]$, and BAP1 overexpression appears to promote basal type breast cancers [24] and myeloid neoplasms harboring certain ATRX mutations [25]. Also, a recent meta-analysis of 26 BAP1 expression studies in 10 different cancer types concludes that the prognostic implication of BAP1 alterations depends on the tumor type [26]. Little is known about alterations of BAP1 in PCa. One study reported lack of BAP1 mutations in 45 prostate tumors [27], but data on BAP1 protein expression or its prognostic significance in this disease are currently acking.

To study the clinical impact of BAP1, we immunohistochemically analyzed more than $17.000 \mathrm{PCa}$, which have been assembled on a tissue microarray during the last 10 years.

\section{RESULTS}

\section{Technical issues}

$89.4 \%$ of 17,747 tumor samples were interpretable. The $10.6 \%$ of non-informative cases had

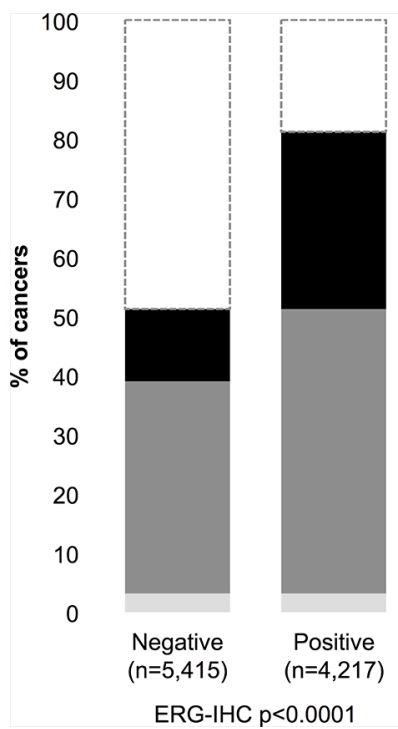

no tissue sample or insufficient unequivocal cancer tissue in the TMA spot.

\section{BAP1 expression in normal and cancerous prostate tissue}

In order to estimate BAP1 expression in normal prostate glands, we studied several spots containing normal tissue. We found that BAP1 staining ranged from negative to moderate in luminal and in basal cells. In PCa, nuclear staining was seen in $62.3 \%$ of 15,857 interpretable tumors. It was considered weak in $3.3 \%$, moderate in $41.6 \%$ and strong in $17.4 \%$ of PCa. Tissue spots with normal and cancerous glands usually showed higher BAP1 levels in the tumor cells than in normal glands, although there were also rare cases with lower relative BAP1 levels in the cancer cells. Tumors with negative findings typically also lacked BAP1 staining in the adjacent normal tissues. Representative images of nuclear BAP1 staining are shown in Figure 1.

\section{BAP1 expression and TMPRSS2:ERG fusion status}

BAP1 staining results were compared with TMPRSS2:ERG data obtained by FISH from 6,476 and by immunohistochemistry from 9,632 tumors. Both, ERG FISH and IHC data were available from 5,365 of these cancers, and concordant results were found in $95.8 \%$ cancers. Nuclear BAP1 expression was associated withTMPRSS2:ERG rearrangement and ERG expression: Strong BAP1 positivity increased from 12$14 \%$ in 5,415 ERG-negative cancers (by IHC or FISH)

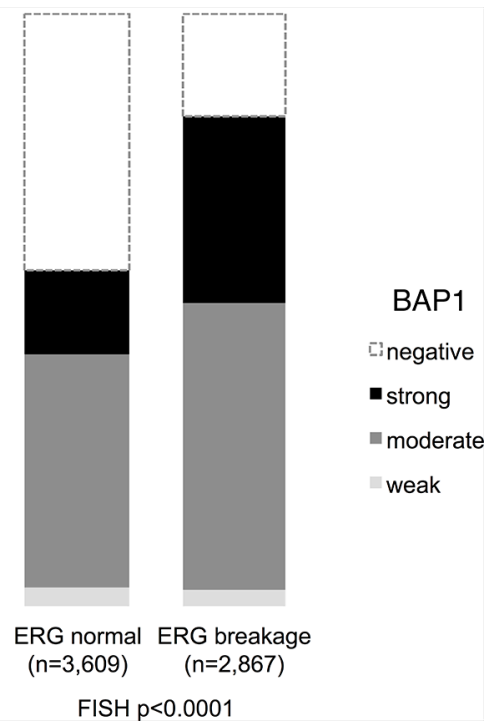

Figure 2: Association between BAP1 staining intensity and ERG status defined by immunohistochemistry (IHC) and fluorescence in-situ hybridization (FISH) analysis. 
Table 1: Association between BAP1 immunostaining and prostate cancer phenotype

\begin{tabular}{|c|c|c|c|c|c|c|}
\hline \multirow[b]{2}{*}{ Parameter } & \multicolumn{6}{|c|}{ BAP1 (\%) } \\
\hline & $\mathbf{N}$ & Negative & Weak & Moderate & Strong & $\mathbf{P}$ \\
\hline All cancers & 15857 & 37.7 & 3.3 & 41.6 & 17.4 & \\
\hline Tumor stage & & & & & & $<0.0001$ \\
\hline pT2 & 10166 & 41.2 & 3.0 & 39.2 & 16.6 & \\
\hline pT3a & 3508 & 32.9 & 3.9 & 44.2 & 19.0 & \\
\hline pT3b-pT4 & 2119 & 28.7 & 3.6 & 48.5 & 19.3 & \\
\hline Gleason grade & & & & & & $<0.0001$ \\
\hline$\leq 3+3$ & 3041 & 43.7 & 2.7 & 38.2 & 15.4 & \\
\hline $3+4$ & 8394 & 38.3 & 3.3 & 40.1 & 18.2 & \\
\hline $3+4$ Tert. 5 & 732 & 39.1 & 3.0 & 42.2 & 15.7 & \\
\hline $4+3$ & 1543 & 30.6 & 4.0 & 47.4 & 18.0 & \\
\hline $4+3$ Tert. 5 & 1096 & 30.3 & 3.2 & 48.1 & 18.4 & \\
\hline$\geq 4+4$ & 910 & 31.6 & 4.0 & 47.7 & 16.7 & \\
\hline $\begin{array}{l}\text { Lymph node } \\
\text { metastasis }\end{array}$ & & & & & & $<0.0001$ \\
\hline N0 & 9573 & 36.2 & 3.5 & 42.1 & 18.1 & \\
\hline $\mathrm{N}+$ & 1162 & 29.3 & 3.4 & 49.1 & 18.1 & \\
\hline $\begin{array}{l}\text { Preoperative } \\
\text { PSA level (ng/ } \\
\text { ml) }\end{array}$ & & & & & & $<0.0001$ \\
\hline$<4$ & 1929 & 32.6 & 2.6 & 44.0 & 20.8 & \\
\hline $4-10$ & 9357 & 37.7 & 3.1 & 41.3 & 17.9 & \\
\hline $10-20$ & 3330 & 39.6 & 3.5 & 41.1 & 15.8 & \\
\hline$>20$ & 1140 & 41.2 & 5.0 & 40.7 & 13.1 & \\
\hline $\begin{array}{l}\text { Surgical } \\
\text { margin }\end{array}$ & & & & & & 0.0019 \\
\hline Negative & 12697 & 38.4 & 3.2 & 41.2 & 17.2 & \\
\hline Positive & 3104 & 34.8 & 3.7 & 43.2 & 18.2 & \\
\hline
\end{tabular}


Table 2: BAP1 immunostaining and prostate cancer phenotype in ERG negative cancers

\begin{tabular}{|c|c|c|c|c|c|c|}
\hline \multirow[b]{2}{*}{ Parameter } & \multicolumn{6}{|c|}{ BAP1 (\%) } \\
\hline & $\mathbf{N}$ & Negative & Weak & Moderate & Strong & $\mathbf{P}$ \\
\hline All cancers & 5415 & 48.7 & 3.3 & 35.8 & 12.2 & \\
\hline Tumor stage & & & & & & $<0.0001$ \\
\hline pT2 & 3643 & 52.1 & 2.8 & 33.8 & 11.2 & \\
\hline pT3a & 1079 & 45.8 & 5.1 & 36.6 & 12.5 & \\
\hline pT3b-pT4 & 677 & 34.9 & 3.1 & 44.9 & 17.1 & \\
\hline Gleason grade & & & & & & $<0.0001$ \\
\hline$\leq 3+3$ & 1090 & 58.3 & 2.8 & 29.2 & 9.7 & \\
\hline $3+4$ & 2879 & 50.2 & 3.3 & 34.9 & 11.6 & \\
\hline $3+4$ Tert. 5 & 243 & 44.9 & 1.6 & 40.7 & 12.8 & \\
\hline $4+3$ & 566 & 39.9 & 4.4 & 41.9 & 13.8 & \\
\hline $4+3$ Tert .5 & 328 & 36.3 & 4.0 & 43.0 & 16.8 & \\
\hline$\geq 4+4$ & 305 & 33.8 & 3.9 & 43.9 & 18.4 & \\
\hline $\begin{array}{l}\text { Lymph node } \\
\text { metastasis }\end{array}$ & & & & & & $<0.0001$ \\
\hline N0 & 3149 & 46.0 & 3.7 & 37.2 & 13.1 & \\
\hline $\mathrm{N}+$ & 310 & 31.9 & 2.9 & 46.5 & 18.7 & \\
\hline $\begin{array}{l}\text { Preoperative } \\
\text { PSA level (ng/ } \\
\text { ml) }\end{array}$ & & & & & & 0.0482 \\
\hline$<4$ & 578 & 44.8 & 2.9 & 38.1 & 14.2 & \\
\hline $4-10$ & 3213 & 48.8 & 3.0 & 35.9 & 12.3 & \\
\hline $10-20$ & 1167 & 50.1 & 3.3 & 35.1 & 11.4 & \\
\hline$>20$ & 430 & 48.8 & 6.3 & 33.0 & 11.9 & \\
\hline $\begin{array}{l}\text { Surgical } \\
\text { margin }\end{array}$ & & & & & & 0.0908 \\
\hline Negative & 4341 & 49.4 & 3.3 & 35.5 & 11.8 & \\
\hline Positive & 1060 & 45.6 & 3.5 & 37.0 & 14.0 & \\
\hline
\end{tabular}

to $30-32 \%$ in 4,217 ERG-positive cancers $(\mathrm{p}<0.0001$ each, Figure 2).

\section{BAP1 expression and tumor phenotype}

Strong BAP1 staining was associated with adverse tumor features, including advanced tumor stage, high Gleason grade, presence of lymph node metastasis $(\mathrm{p}<0.0001$ each) and a positive surgical margin $(\mathrm{p}=0.0019$, Table 1). Because of the strong link between BAP1 overexpression and ERG rearrangement, the analysis was repeated in the subsets of ERG-negative and ERG-positive cancers. It showed that all associations were solely driven by the subset of ERG-negative cancers (Table 2), while BAP1 staining was unrelated to the analyzed features in ERG-positive cancers (Table 3). 
Table 3: BAP1 immunostaining and prostate cancer phenotype in ERG positive cancers

\begin{tabular}{|c|c|c|c|c|c|c|}
\hline \multirow[b]{2}{*}{ Parameter } & \multicolumn{6}{|c|}{ BAP1 (\%) } \\
\hline & $\mathbf{N}$ & Negative & Weak & Moderate & Strong & $\mathbf{P}$ \\
\hline All cancers & 4217 & 18.8 & 3.1 & 48.1 & 30.0 & \\
\hline Tumor stage & & & & & & 0.0065 \\
\hline pT2 & 2508 & 20.7 & 2.8 & 47.0 & 29.4 & \\
\hline pT3a & 1111 & 16.7 & 3.4 & 49.6 & 30.3 & \\
\hline pT3b-pT4 & 580 & 14.5 & 3.8 & 50.0 & 31.7 & \\
\hline Gleason grade & & & & & & 0.0729 \\
\hline$\leq 3+3$ & 862 & 21.9 & 2.9 & 49.8 & 25.4 & \\
\hline $3+4$ & 2412 & 18.6 & 3.1 & 46.8 & 31.5 & \\
\hline $3+4$ Tert. 5 & 128 & 21.9 & 3.1 & 45.3 & 29.7 & \\
\hline $4+3$ & 409 & 14.9 & 4.2 & 52.1 & 28.9 & \\
\hline $4+3$ Tert. 5 & 232 & 16.4 & 3.0 & 47.8 & 32.8 & \\
\hline$\geq 4+4$ & 171 & 17.0 & 2.3 & 51.5 & 29.2 & \\
\hline $\begin{array}{l}\text { Lymph node } \\
\text { metastasis }\end{array}$ & & & & & & 0.2321 \\
\hline N0 & 2413 & 17.3 & 3.4 & 47.5 & 31.9 & \\
\hline $\mathrm{N}+$ & 271 & 19.2 & 3.7 & 51.3 & 25.8 & \\
\hline $\begin{array}{l}\text { Preoperative } \\
\text { PSA level (ng/ } \\
\text { ml) }\end{array}$ & & & & & & 0.4984 \\
\hline$<4$ & 582 & 17.0 & 2.9 & 49.5 & 30.6 & \\
\hline $4-10$ & 2587 & 19.1 & 3.2 & 47.3 & 30.4 & \\
\hline $10-20$ & 763 & 18.7 & 2.9 & 48.1 & 30.3 & \\
\hline$>20$ & 252 & 20.6 & 3.6 & 52.8 & 23.0 & \\
\hline $\begin{array}{l}\text { Surgical } \\
\text { margin }\end{array}$ & & & & & & 0.0639 \\
\hline Negative & 3314 & 19.6 & 3.1 & 47.7 & 29.5 & \\
\hline Positive & 884 & 15.7 & 3.1 & 49.7 & 31.6 & \\
\hline
\end{tabular}

\section{BAP1 expression and tumor cell proliferation}

Presence of BAP1 staining was linked to increased proliferation as determined by the Ki67 labeling index (Table 4). This association was independent of the Gleason grade as it was observed across subsets with identical Gleason score $(\leq 3+3,3+4,3+4$ tertiary $5,4+3$, $\geq 4+4 \mathrm{p}<0.0001$ each and $4+3$ tert. $5 ; \mathrm{p} \leq 0.0057$ ). Again, subset analyses demonstrated that these associations were driven from the ERG negative subset $(\mathrm{p} \leq 0.0007$ each).

\section{BAP1 and androgen receptor (AR) expression}

Data on BAP1 and AR were available from 7,151 cancers [28]. AR expression was associated with nuclear BAP1 staining. Only $2 \%$ of AR-negative, but $33 \%$ of 
strongly AR expressing cancers had strong BAP1 expression $(\mathrm{p}<0.0001)$. This association held true regardless of the ERG fusion status ( $p<0.0001$ each; Figure 3 ).

\section{BAP1 expression and PSA recurrence}

Nuclear BAP1 staining was linked to early biochemical recurrence $(p<0.0001$, Figure 4). ERG subset analysis revealed, that the prognostic impact of BAP1 expression was contributed by the ERG negative subset $(\mathrm{p}<0.0001)$. BAP1 expression was unrelated to patient outcome in the ERG-positive subset $(p=0.1248)$. A further analysis in the ERG-negative subset revealed that, for subgroups with identical classical and quantitative Gleason grades, BAP1 expression only had a prognostic impact for Gleason $3+4$ carcinomas $(p=0,006$; Figure 5).

\section{Multivariate analysis}

Four different scenarios were tested (Table 5). Scenarios 1 and 2 evaluated postoperatively available parameters (stage, with/without lymph node status $(\mathrm{pN})$, margin status, preoperative PSA value and pathological Gleason grade). Scenario 3 was a mixed model of post- and preoperatively available parameters, while in scenario 4 the preoperative parameters were combined (Gleason grade obtained on the original biopsy, preoperative PSA, cT stage and BAP1 expression). BAP1 expression was an independent prognosticator in $\mathrm{PCa}(\mathrm{p}<0.02)$ and in the ERG-negative subset $(\mathrm{p}<0.005$ each $)$.

\section{DISCUSSION}

In this study we show that nuclear BAP1 expression is an independent predictor of poor prognosis in ERG negative $\mathrm{PCa}$.

Nuclear BAP1 staining was seen in $62 \%$ of PCa, including $17,4 \%$ tumors with strong BAP1 staining intensity. Normal prostatic epithelial tissue showed variable but generally lower BAP1 expression levels ranging between negative and moderate positive staining. That BAP1 staining intensities were often higher in cancer cells than in adjacent normal prostate glands suggests that BAP1 usually becomes overexpressed during tumor development. Comparable studies on BAP1 in prostate tissues are currently lacking in the published literature. However, the human protein atlas (https:// www.proteinatlas.org/ENSG00000163930-BAP1/tissue/ prostate) shows examples of BAP1 staining that are in line with our findings, including six samples of normal prostate glands (with low to medium intensity staining) and 23 samples of PCa with variable levels of positivity ranging from negative to strong using two different antiBAP1 antibodies including HPA028814, which was used in our study [29].

A strong association between BAP1 up regulation, adverse tumor phenotype and clinical outcome was found in our cohort of more than 15.800 patients. Similar findings have been reported from malignant pleural mesotheliomas, where BAP1 overexpression was also linked to aggressive tumor features or shortened survival $[15,30-33]$. These observations are in contrast to data described for most other tumor types that have been

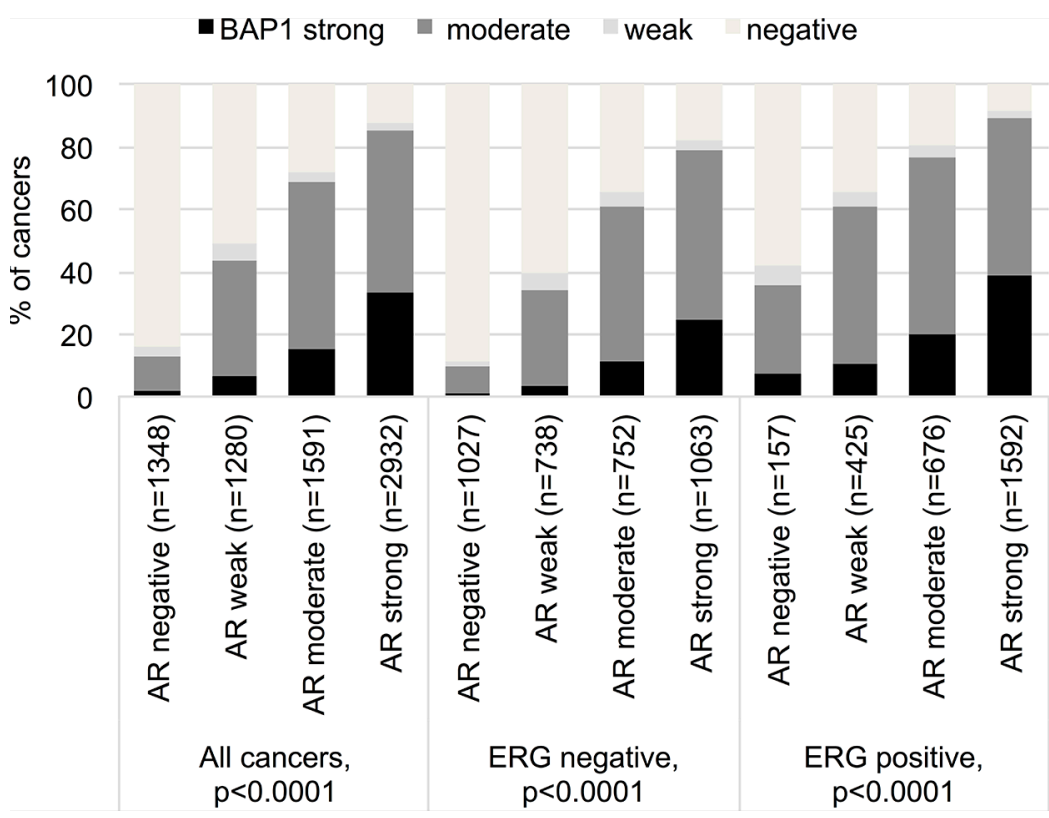

Figure 3: Correlation between BAP1 staining and androgen receptor expression in all cancers, the ERG expression negative and positive subset (IHC). 
Table 4: Association between BAP1 immunostaining and Ki67 labeling index in Gleason categories and ERG-fusion subsets

\begin{tabular}{|c|c|c|c|c|c|c|c|c|c|c|c|c|c|c|c|c|}
\hline \multirow{2}{*}{ Gleason } & \multirow{2}{*}{ BAP1 } & \multicolumn{5}{|c|}{ All cancers } & \multicolumn{5}{|c|}{ ERG-fusion negative } & \multicolumn{5}{|c|}{ ERG-fusion positive } \\
\hline & & $\mathbf{n}$ & Ki67LI ${ }^{*}$ & & & $\boldsymbol{P}$ & $\mathbf{n}$ & Ki67LI & & & $P$ & $\mathbf{n}$ & Ki67LI & & & $P$ \\
\hline \multirow[t]{4}{*}{ All } & Negative & 2243 & 2.0 & \pm & 0.06 & \multirow{4}{*}{$<0.0001$} & 1706 & 1.85 & \pm & 0.07 & \multirow{4}{*}{$<0.0001$} & 499 & 2.39 & \pm & 0.12 & \multirow{4}{*}{$<0.0001$} \\
\hline & Weak & 226 & 2.9 & \pm & 0.18 & & 131 & 3.0 & \pm & 0.24 & & 92 & 2.72 & \pm & 0.27 & \\
\hline & Moderate & 2613 & 3.13 & \pm & 0.05 & & 1196 & 3.38 & \pm & 0.08 & & 1365 & 2.93 & \pm & 0.07 & \\
\hline & Strong & 1265 & 3.47 & \pm & 0.07 & & 386 & 3.86 & \pm & 0.14 & & 849 & 3.33 & \pm & 0.09 & \\
\hline \multirow[t]{4}{*}{$\leq 3+3$} & Negative & 591 & 1.64 & \pm & 0.08 & \multirow{4}{*}{$<0.0001$} & 442 & 1.51 & \pm & 0.1 & \multirow{4}{*}{$<0.0001$} & 130 & 2.08 & \pm & 0.17 & \multirow{4}{*}{0.0015} \\
\hline & Weak & 39 & 3.0 & \pm & 0.33 & & 17 & 2.94 & \pm & 0.52 & & 20 & 3.0 & \pm & 0.44 & \\
\hline & Moderate & 503 & 2.4 & \pm & 0.09 & & 179 & 2.69 & \pm & 0.16 & & 307 & 2.27 & \pm & 0.11 & \\
\hline & Strong & 229 & 2.93 & \pm & 0.14 & & 57 & 3.33 & \pm & 0.28 & & 162 & 2.86 & \pm & 0.15 & \\
\hline \multirow[t]{4}{*}{$3+4$} & Negative & 1221 & 2.0 & \pm & 0.07 & \multirow{4}{*}{$<0.0001$} & 922 & 1.84 & \pm & 0.07 & \multirow{4}{*}{$<0.0001$} & 284 & 2.32 & \pm & 0.14 & \multirow{4}{*}{$<0.0001$} \\
\hline & Weak & 122 & 2.6 & \pm & 0.21 & & 70 & 2.61 & \pm & 0.27 & & 52 & 2.58 & \pm & 0.32 & \\
\hline & Moderate & 1442 & 2.89 & \pm & 0.06 & & 639 & 2.92 & \pm & 0.09 & & 781 & 2.87 & \pm & 0.08 & \\
\hline & Strong & 749 & 3.32 & \pm & 0.08 & & 196 & 3.34 & \pm & 0.16 & & 539 & 3.32 & \pm & 0.1 & \\
\hline \multirow[t]{4}{*}{$\begin{array}{l}3+4 \\
\text { Tertiary } \\
5\end{array}$} & Negative & 99 & 2.33 & \pm & 0.26 & & 78 & 2.21 & \pm & 0.28 & & 21 & 2.81 & \pm & 0.57 & \multirow{4}{*}{0.1641} \\
\hline & Weak & 6 & 5.33 & \pm & 1.05 & \multirow[t]{3}{*}{$<0.0001$} & 3 & 7.67 & \pm & 1.43 & \multirow[t]{3}{*}{$<0.0001$} & 3 & 3.0 & \pm & 1.51 & \\
\hline & Moderate & 100 & 3.74 & \pm & 0.26 & & 64 & 3.42 & \pm & 0.31 & & 36 & 4.31 & \pm & 0.44 & \\
\hline & Strong & 50 & 3.76 & \pm & 0.36 & & 22 & 4.64 & \pm & 0.53 & & 25 & 3.2 & \pm & 0.52 & \\
\hline \multirow[t]{4}{*}{$4+3$} & Negative & 180 & 2.47 & \pm & 0.25 & \multirow{4}{*}{$<0.0001$} & 139 & 2.34 & \pm & 0.3 & \multirow{4}{*}{$<0.0001$} & 38 & 3.0 & \pm & 0.46 & \multirow{4}{*}{0.8606} \\
\hline & Weak & 37 & 2.84 & \pm & 0.54 & & 24 & 2.92 & \pm & 0.73 & & 12 & 2.83 & \pm & 0.81 & \\
\hline & Moderate & 284 & 3.84 & \pm & 0.2 & & 152 & 4.3 & \pm & 0.29 & & 126 & 3.25 & \pm & 0.25 & \\
\hline & Strong & 102 & 3.67 & \pm & 0.33 & & 43 & 4.05 & \pm & 0.54 & & 59 & 3.39 & \pm & 0.37 & \\
\hline \multirow[t]{4}{*}{$\begin{array}{l}4+3 \\
\text { Tertiary } \\
5\end{array}$} & Negative & 93 & 2.7 & \pm & 0.38 & & 77 & 2.49 & \pm & 0.43 & & 15 & 3.87 & \pm & 0.91 & \\
\hline & Weak & 9 & 3.22 & \pm & 1.24 & 0.0057 & 7 & 3.57 & \pm & 1.43 & 0.0007 & 2 & 2.0 & \pm & 2.5 & 0.7141 \\
\hline & Moderate & 147 & 4.15 & \pm & 0.31 & & 76 & 4.72 & \pm & 0.44 & & 67 & 3.46 & \pm & 0.43 & \\
\hline & Strong & 73 & 4.56 & \pm & 0.43 & & 33 & 5.15 & \pm & 0.66 & & 38 & 4.13 & \pm & 0.57 & \\
\hline$\geq 4+4$ & Negative & 58 & 2.21 & \pm & 0.61 & & 48 & 2.0 & \pm & 0.57 & & 10 & 3.1 & \pm & 1.89 & \\
\hline & Weak & 13 & 4.15 & \pm & 1.29 & ( & 10 & 4.5 & \pm & 1.25 & & 3 & 3.0 & \pm & 3.44 & 06276 \\
\hline & Moderate & 135 & 5.39 & \pm & 0.4 & $<0.0001$ & 84 & 5.42 & \pm & 0.43 & $<0.0001$ & 48 & 5.44 & \pm & 0.86 & 0.6276 \\
\hline & Strong & 61 & 5.57 & \pm & 0.59 & & 35 & 5.69 & \pm & 0.67 & & 25 & 5.48 & \pm & 1.19 & \\
\hline
\end{tabular}

${ }^{*}$ Mean \pm standard error of the mean

analyzed for BAP1 alterations so far. Reduced BAP1 expression has been linked to poor prognosis and adverse tumor features in renal carcinoma [10-12], colorectal cancer [34], gastric adenocarcinoma [35], non-small cell lung cancer [8,9], gall bladder cancer [13] and uveal melanoma $[16-18,36]$. These data suggest that BAP1 may function differently in different tumor types. Whereas the tumor suppressive role has been attributed to BAP1's important involvement in DNA double strand breakage repair [37], there is emerging evidence that BAP1 can also promote tumor growth when it is overexpressed in particular molecular environments. For example, target genes of BAP1 deubiquitination include mutant ATRX in myeloid neoplasms [25] and Krüppellike factor 5 (KLF5) in basal-like breast cancers [24], which both become stabilized by BAP1 and consequently 
accelerate tumor growth $[24,25]$. That BAP1 interacts with KLF5 is of potential interest. KLF5 is a hormoneregulated gene in $\mathrm{PCa}$ and may have an oncogenic or tumor suppressive role depending on posttranscriptional modifications [38-40].

Our analysis of molecularly defined tumor subgroups revealed that the prognostic impact of BAP1 was almost entirely driven by the ERG negative subset. About 50 percent of PCa carry TMPRSS2:ERG fusions $[41,42]$ leading to a constitutive overexpression of ERG [28]. ERG overexpression by itself had no prognostic relevance, at least in patients not receiving systemic therapy [43]. However, ERG regulates more than 1,600 genes in prostate epithelial cells. Some proteins are mitigated, others intensified. The substantially higher BAP1 expression in ERG positive $(30 \%$ with strong BAP1 positivity) than in ERG negative cancers (12\% with strong BAP1 positivity) provides strong in vivo evidence for an ERG-BAP1 interaction. BAP1 may be directly regulated by ERG, since analysis of the BAP1 promoter/ enhancer region using GeneHancer [44] indicates binding sites for 179 transcription factors, including one for ETS transcription factors such as ERG. A functional interaction may also exist through BAP1's binding partner BRCA1, which contributes to the regulation of WNT-signaling [45]. Activation of Wnt signaling ranks among to the best-known consequences of ERG activation [41, 46, 47], and it can be assumed that most factors involved in this pathway undergo expression changes once ERG becomes active.

That BAP1 expression didn't change patient outcome in the ERG positive subset argues for circumstances related to the ERG specific cellular microenvironment not only modifying BAP1 expression levels but also impacting its biological effects. This phenomenon has been observed in earlier studies, in which various molecular features were observed that were exclusively prognostic in ERG positive (SOX9, [48]; AZGP1, [49]; HOOK3, [50] or in ERG negative cancers (YB-1, [51], p16, [52], BCAR1, [53]), but not in both groups. As an alternative explanation for the lack of prognostic impact of BAP1 in the ERG positive subset, we cannot rule out that our experimental set-up was more sensitive to expression differences at the lower level (ERG negative subset) than at the higher level (ERG positive subset). Irrespective of the underlying mechanism, the selective prognostic impact of BAP1 in ERG negative cancers demonstrate, that the applicability (and perhaps thresholds) of prognostic markers may depend on individual molecular tumor features. This represents a challenge for the development of biomarkers that, ideally are applicable to every patient.

Other molecular markers with associations to BAP1 up regulation included androgen receptor and the Ki67 cell proliferation marker. The massive increase of BAP1 expression with AR expression strongly suggests a functional interaction. This is supported by one in vitro study showing that androgen signaling was among the pathways that become deregulated in a cell line model harboring an inactivating BAP1 mutation [54]. The massive increase of BAP1 expression with tumor cell proliferation was expected, as BAP1 regulates cell proliferation via deubiquitination of its target protein host cell factor-1 (HCF1), which plays a critical role at multiple stages of the cell cycle $[55,56]$. That the impact of BAP1 on proliferation was much stronger in ERG negative than in ERG positive cancer further supports the

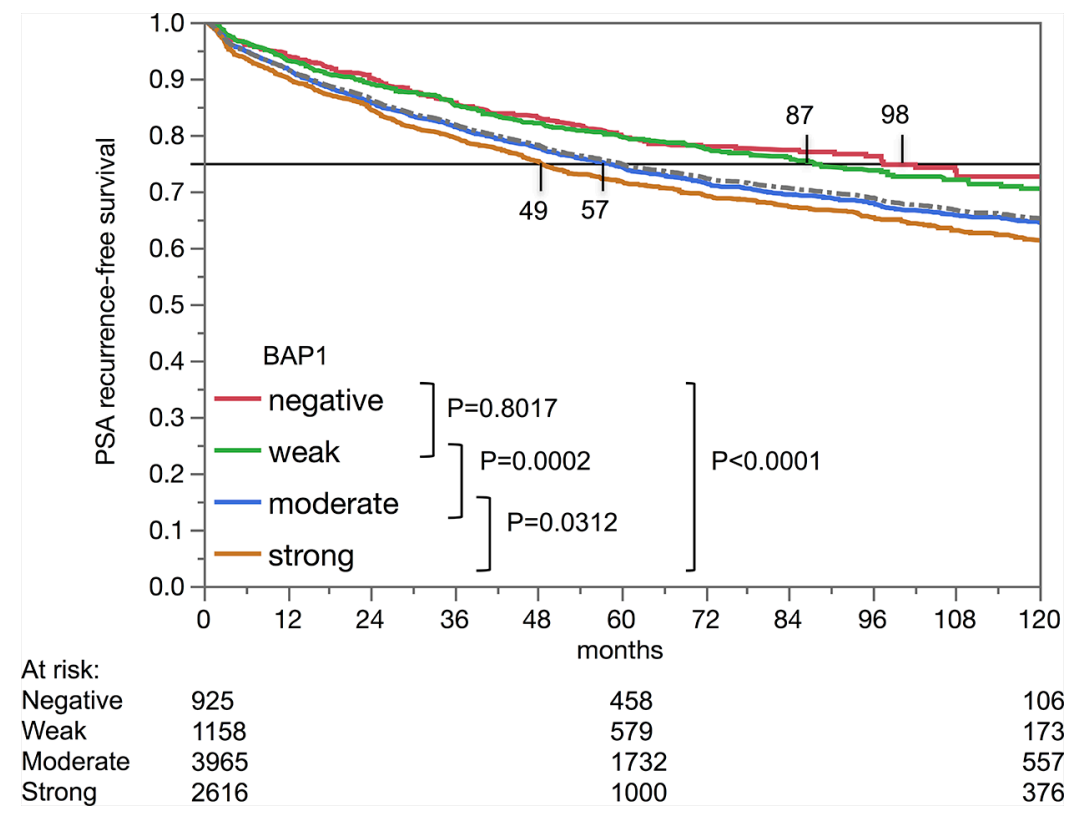

Figure 4: Kaplan-Meier analysis of PSA recurrence-free survival after prostatectomy and BAP1 staining. 
notion that ERG activation may interfere with functions of BAP1.

The results of this study suggest that BAP1 expression may represent a useful marker in ERG negative cancer. In this subset, BAP1 expression had a significant impact, which was independent of established prognostic parameters, irrespective of whether all available features or only preoperatively available prognostic parameters were included into the analysis. It should be noted, however, that its independent prognostic relevance is not the only important criterion for a prognostic feature in PCa. Most established prognostic parameters that are typically included into multivariate analyses in PCa studies are statistically strong but suffer from shortcomings in clinical practice. pT stage and nodal status cannot be determined before the prostate

is surgically removed and therefore cannot be used for preoperative therapeutic decision-making. Even in the postoperative situation, the detection rate of lymph node metastasis is highly variable and greatly depends on the extent of surgery and the pathological work-up of the removed tissue [57]. Gleason grade, the most powerful prognostic marker available preoperatively, suffers from substantial interobserver variability, reaching up to $40 \%$ in individual biopsies [58]. That BAP1 expression lacks prognostic impact in cancers with identical quantitative Gleason grade demonstrates the statistical power of the quantitative Gleason grading system, however, it is not universally applied and does not solve all issues of interobserver variability in PCa grading.

In summary, up regulation of BAP1 is associated with adverse features, rapid cell proliferation and poor
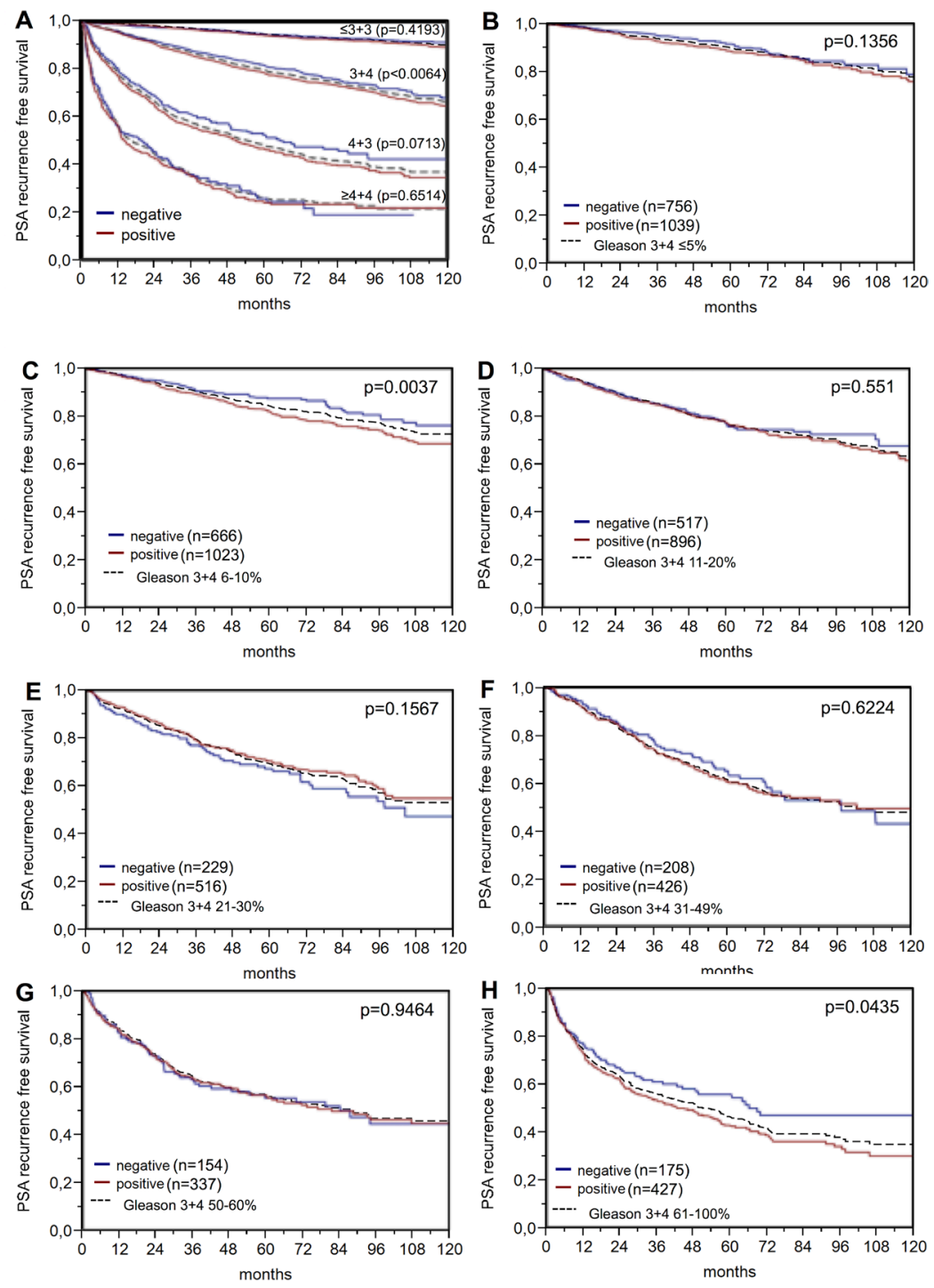

Figure 5: PSA recurrence-free survival after prostatectomy and BAP1 negative versus positive expression in subsets of the ERG expression negative cohort defined by (A) the classical Gleason score categories and (B-H) the quantitative Gleason score grades defined by the percentage of (B) $\leq 5 \%$, (C) $6-10 \%$, (D) $11-20 \%$, (E) $21-30 \%$, (F) $31-49 \%$, (G) 50-60\%, and (H) $\geq 61 \%$ Gleason 4 patterns. Dashed line shows the combined result of the respective Gleason category for reference. 
Table 5: Hazard ratios (95\% confidence intervals) for biochemical relapse after prostatectomy of established risk factors and BAP1 expression in prostate cancer, the ERG negative and positive subsets

\begin{tabular}{|c|c|c|c|c|c|c|}
\hline Subset & Model & & Scenario 4 & Scenario 3 & Scenario 2 & Scenario 1 \\
\hline & Variable & Analyzable $(\mathrm{N})$ & 8,171 & 8,512 & 8,628 & 5,450 \\
\hline \multirow[t]{8}{*}{ Total } & $\begin{array}{c}\text { Gleason grade } \\
\text { biopsy }\end{array}$ & $\geq 4+4$ vs. $\leq 3+3$ & $4.20 \underset{* * *}{(3.69-4.77)}$ & & & \\
\hline & cT stage & T2c vs. T1c & $1.92 \underset{* * *}{(1.54-2.38)}$ & $1.70(1.37-2.11)$ & & \\
\hline & $\begin{array}{l}\text { Preoperative } \\
\text { PSA level }\end{array}$ & $\geq 20$ vs. $<4$ & $3.04 \underset{* * *}{(2.49-4.46)}$ & $2.85 \underset{* * *}{(2.36-3.44)}$ & $1.98 \underset{* * *}{(1.65-2.39)}$ & $1.80 \underset{* * *}{(1.46-2.22)}$ \\
\hline & $\begin{array}{c}\text { BAP1 } \\
\text { expression }\end{array}$ & $\begin{array}{l}\text { Strong vs. } \\
\text { negative }\end{array}$ & $1.49 \underset{* * *}{(1.27-1.77)}$ & $1.38 \underset{* * *}{(1.17-1.63)}$ & $1.32 \underset{* *}{(1.13-1.56)}$ & $1.45(1.21-1.76)$ \\
\hline & $\begin{array}{l}\text { Gleason grade } \\
\text { prostatectomy }\end{array}$ & $\geq 4+4$ vs. $\leq 3+3$ & & $13.0 \underset{* * *}{(10.6-15.8)}$ & $6.56 \underset{* * *}{(5.32-8.10)}$ & $5.57 \underset{* * *}{(4.25-7.29)}$ \\
\hline & pT stage & T4 vs. T2 & & & $3.06(2.71-3.46)$ & $2.77 \underset{* * *}{(2.40-3.21)}$ \\
\hline & $\begin{array}{c}\text { Resection } \\
\text { margin status }\end{array}$ & R1 vs. R0 & & & $1.39 \underset{* * *}{(1.27-1.53)}$ & $1.25(1.12-1.39)$ \\
\hline & Nodal stage & $\mathrm{N}+$ vs. N0 & & & & $1.46(1.27-1.67)$ \\
\hline \multirow[t]{2}{*}{ ERG neg. } & & Analyzable $(\mathrm{N})$ & 3,962 & 4,104 & 4,144 & 2,681 \\
\hline & $\begin{array}{c}\text { BAP1 } \\
\text { expression }\end{array}$ & $\begin{array}{l}\text { Strong vs. } \\
\text { negative }\end{array}$ & $1.71 \underset{* * *}{(1.38-2.12)}$ & $1.53 \underset{* * *}{(1.24-1.88)}$ & $1.45(1.18-1.79)$ & $1.63 \underset{* * *}{(1.28-2.08)}$ \\
\hline \multirow[t]{2}{*}{ ERG pos. } & & Analyzable $(\mathrm{N})$ & 3,194 & 3,355 & 3,414 & 2,192 \\
\hline & $\begin{array}{c}\text { BAP1 } \\
\text { expression }\end{array}$ & $\begin{array}{l}\text { Strong vs. } \\
\text { negative }\end{array}$ & $1.44(0.92-2.45)$ & $1.47(0.94-2.50)$ & $1.29(0.81-2.08)$ & $1.24(0.77-2.14)$ \\
\hline
\end{tabular}

Scenario 4 combines preoperatively available parameter (Gleason score obtained on the original biopsy, clinical tumor (cT) stage, and PSA level) with the postoperative BAP1 expression. In scenario 3 the Gleason at biopsy is replaced by the Gleason obtained on radical prostatectomy. In scenario 2, cT-stage is superseded by pathological tumor (pT) stage and surgical margin (R) status. In scenario 1 the lymph node $(\mathrm{pN})$ stage is added. ${ }^{*} \mathrm{p} \leq 0.05,{ }^{* *} \mathrm{p} \leq 0.001,{ }^{* * *} \mathrm{p} \leq 0.0001$

patient prognosis in PCa. BAP1 expression analysis may have prognostic utility either alone or, more likely, in combination with other biomarkers.

\section{MATERIALS AND METHODS}

\section{Patients}

The 17,747 patients had radical prostatectomy at the Department of Urology and the Martini Clinic at the University Medical Center Hamburg-Eppendorf between 1992 and 2015. Specimens were analyzed according to a standard procedure [59]. Classical Gleason categories and "quantitative" Gleason grading was performed as described previously [58]. In brief, for quantitative Gleason grading the percentage of Gleason 4 patterns was recorded and the $3+4$ and $4+3$ cancers subdivided in subgroups with $\leq 5 \%, 6-10 \%, 11-20 \%, 21-30 \%, 31-$ $49 \%$, respective $50-60 \%, 61-80 \%$ and $>80 \%$ Gleason 4 pattern. Follow-up for the time to PSA recurrence was available for a total of 12,859 patients (median 48 months, range: 1 to 276 months; Table 6). Prostate specific antigen (PSA) levels were measured following surgery and PSA recurrence was defined as a postoperative PSA of at least $0.2 \mathrm{ng} / \mathrm{ml}$ and increasing at subsequent measurements. The TMA was manufactured as described earlier in detail [60]. A corresponding TMA database contained prior results on ERG expression, $E R G$ break apart FISH 
No. of patients $(\%)$

Study cohort on TMA*

Biochemical relapse among categories

\section{Follow-up}

$\mathrm{N}$

Mean/median-time to PSA recurrence

(month)

Age (y)

$\leq 50$

$51-59$

60-69

$\geq 70$

Pretreatment PSA (ng/ml)

$<4$

4-10

$10-20$

$>20$

pT stage (AJCC 2002)

pT2

11518

3842

2233

85

pT4

Gleason grade

$\leq 3+3$

3570

9336

1697

2903

1187

999

$\geq 4+4$

pN stage

pNO

10636

1255

$\mathrm{pN}+$

\section{Surgical margin}

Negative

14297

Positive
3388
2307

$66(15.2 \%)$

839 (19.3\%)

2073 (20.8\%)

$634(21.6 \%)$

$313(14.1 \%)$

$1696(16.1 \%)$

1043 (28.5\%)

545 (44.3\%)

$1212(10.5 \%)$

$1121(29.2 \%)$

1213 (54.3\%)

$63(74.1 \%)$

$264(7.4 \%)$

1436 (15.4\%)

$165(9.7 \%)$

$683(23.5 \%)$

487 (41\%)

$531(53.2 \%)$

$2243(21.1 \%)$

$700(55.8 \%)$

1304

* Numbers do not always add up to 17747 in the different categories because of cases with missing data. Abbreviation: AJCC, American Joint Committee on Cancer. 
analysis [43], Ki67 labeling index (Ki67LI) data [61], androgen receptor (AR) expression [28], and deletion status of 5q21 (CHD1) [62], 6q15 (MAP3K7) [63], PTEN (10q23) [64], 3p13 (FOXP1) [65]. The use of anonymized diagnostic leftover tissues was in accordance with local laws (HmbKHG, §12a) and approved by the local ethics committee (Ethics Commission Hamburg, WF-049/09). All work has been carried out in compliance with the Helsinki Declaration.

\section{Immunohistochemistry}

Freshly cut TMA sections were immunostained in one experiment. Slides were deparaffinized and exposed to $121^{\circ} \mathrm{C}$ in $\mathrm{pH} 7.8$ Tris-EDTA buffer for 5 minutes. HPA028814 primary antibody specific for BAP1 (rabbit polyclonal antibody, Sigma-Aldrich, St. Louis, Missouri, USA, dilution $1: 150$ ) was applied at $37^{\circ} \mathrm{C}$ for 60 minutes. This antibody was validated by Western blot and protein array in the human protein atlas [29, 66]. Of note, the product was discontinued while manuscript was under review. Bound antibody was visualized with the EnVision Kit (Dako, Glostrup, Denmark) according to the manufacturer's directions. BAP1 staining was mainly seen in the nucleus and typically paralleled by cytoplasmic staining of lower intensity. Only nuclear staining was scored in this study. As BAP1 typically stained the nucleus in all $(100 \%)$ tumor cells of a BAP1-positive tissue spot, only the staining intensity was assessed on a four-step scale: negative $(0+)$, weak $(1+)$, moderate $(2+)$ and strong $(3+)$. Scoring was done at 100-200x magnifications by a single pathologist.

\section{Statistics}

Contingency tables were analyzed with the $\mathrm{chi}^{2}$-test to search for associations between molecular parameters and tumor phenotype. Kaplan-Meier curves were calculated and the log-rank test was applied to detect differences between groups. Cox proportional hazards regression analysis was performed to test for independence and significance between pathological, molecular and clinical variables. JMP 11 was applied (SAS Institute Inc., NC, USA).

\section{ACKNOWLEDGMENTS}

We thank Wilfried Fehrle for help in revision of the manuscript and Christina Koop, Janett Lütgens, Sünje Seekamp, and Inge Brandt for excellent technical assistance.

\section{CONFLICTS OF INTEREST}

The authors declare no competing financial interests.

\section{REFERENCES}

1. Bray F, Ferlay J, Soerjomataram I, Siegel RL, Torre LA, Jemal A. Global cancer statistics 2018: GLOBOCAN estimates of incidence and mortality worldwide for 36 cancers in 185 countries. CA Cancer J Clin. 2018; 68: 394-424. https://doi.org/10.3322/caac.21492. [PubMed]

2. Bell KJ, Del Mar C, Wright G, Dickinson J, Glasziou P. Prevalence of incidental prostate cancer: A systematic review of autopsy studies. Int J Cancer. 2015; 137: 174957. https://doi.org/10.1002/ijc.29538. [PubMed]

3. Fukuda T, Tsuruga T, Kuroda T, Nishikawa H, Ohta T. Functional Link between BRCA1 and BAP1 through Histone H2A, Heterochromatin and DNA Damage Response. Curr Cancer Drug Targets. 2016; 16: 101-09. https://doi.org/10.2 174/1568009615666151030102427. [PubMed]

4. Jensen DE, Proctor M, Marquis ST, Gardner HP, Ha SI, Chodosh LA, Ishov AM, Tommerup N, Vissing H, Sekido Y, Minna J, Borodovsky A, Schultz DC, et al. BAP1: a novel ubiquitin hydrolase which binds to the BRCA1 RING finger and enhances BRCA1-mediated cell growth suppression. Oncogene. 1998; 16: 1097-112. https://doi. org/10.1038/sj.onc.1201861. [PubMed]

5. Carbone M, Yang H, Pass HI, Krausz T, Testa JR, Gaudino G. BAP1 and cancer. Nat Rev Cancer. 2013; 13:153-59. https://doi.org/10.1038/nrc3459. [PubMed]

6. Citterio E. Fine-tuning the ubiquitin code at DNA double-strand breaks: deubiquitinating enzymes at work. Front Genet. 2015; 6: 282. https://doi.org/10.3389/ fgene.2015.00282. [PubMed]

7. Bononi A, Giorgi C, Patergnani S, Larson D, Verbruggen K, Tanji M, Pellegrini L, Signorato V, Olivetto F, Pastorino S, Nasu M, Napolitano A, Gaudino G, et al. BAP1 regulates IP3R3-mediated $\mathrm{Ca}^{2+}$ flux to mitochondria suppressing cell transformation. Nature. 2017; 546: 549-53. https://doi. org/10.1038/nature22798. [PubMed]

8. Fan LH, Tang LN, Yue L, Yang Y, Gao ZL, Shen Z. BAP1 is a good prognostic factor in advanced non-small cell lung cancer. Clin Invest Med. 2012; 35: E182-89. https://doi. org/10.25011/cim.v35i4.17146. [PubMed]

9. Shen C, Wang Y, Wei P, Du X. BRCA1-associated protein 1 deficiency in lung adenocarcinoma predicts poor outcome and increased tumor invasion. BMC Cancer. 2016; 16:670. https://doi.org/10.1186/s12885-016-2670-x. [PubMed]

10. Minardi D, Lucarini G, Milanese G, Di Primio R, Montironi R, Muzzonigro G. Loss of nuclear BAP1 protein expression is a marker of poor prognosis in patients with clear cell renal cell carcinoma. Urol Oncol. 2016; 34: 338.e11-18. https://doi.org/10.1016/j.urolonc.2016.03.006. [PubMed]

11. Kapur P, Christie A, Raman JD, Then MT, Nuhn P, Buchner A, Bastian P, Seitz C, Shariat SF, Bensalah K, Rioux-Leclercq N, Xie XJ, Lotan Y, et al. BAP1 immunohistochemistry predicts outcomes in a multiinstitutional cohort with clear cell renal cell carcinoma. 
J Urol. 2014; 191: 603-10. https://doi.org/10.1016/j. juro.2013.09.041. [PubMed]

12. Joseph RW, Kapur P, Serie DJ, Eckel-Passow JE, Parasramka M, Ho T, Cheville JC, Frenkel E, Rakheja D, Brugarolas J, Parker A. Loss of BAP1 protein expression is an independent marker of poor prognosis in patients with low-risk clear cell renal cell carcinoma. Cancer. 2014; 120: 1059-67. https://doi.org/10.1002/cncr.28521. [PubMed]

13. Hirosawa $T$, Ishida $M$, Ishii $K$, Kanehara $K$, Kudo K, Ohnuma S, Kamei T, Motoi F, Naitoh T, Selaru FM, Unno M. Loss of BAP1 expression is associated with genetic mutation and can predict outcomes in gallbladder cancer. PLoS One. 2018; 13: e0206643. https://doi.org/10.1371/ journal.pone.0206643. [PubMed]

14. Pulford E, Huilgol K, Moffat D, Henderson DW, Klebe S. Malignant Mesothelioma, BAP1 Immunohistochemistry, and VEGFA: Does BAP1 Have Potential for Early Diagnosis and Assessment of Prognosis? Dis Markers. 2017; 2017: 1310478. https://doi.org/10.1155/2017/1310478. [PubMed]

15. Farzin M, Toon CW, Clarkson A, Sioson L, Watson N, Andrici J, Gill AJ. Loss of expression of BAP1 predicts longer survival in mesothelioma. Pathology. 2015; 47: 302-07. https://doi.org/10.1097/PAT.0000000000000250. [PubMed]

16. Kalirai H, Dodson A, Faqir S, Damato BE, Coupland SE. Lack of BAP1 protein expression in uveal melanoma is associated with increased metastatic risk and has utility in routine prognostic testing. Br J Cancer. 2014; 111: 1373-80. https://doi.org/10.1038/bjc.2014.417. [PubMed]

17. Koopmans AE, Verdijk RM, Brouwer RW, van den Bosch TP, van den Berg MM, Vaarwater J, Kockx CE, Paridaens D, Naus NC, Nellist M, van IJcken WF, Kiliç E, de Klein A. Clinical significance of immunohistochemistry for detection of BAP1 mutations in uveal melanoma. Mod Pathol. 2014; 27: 1321-30. https://doi.org/10.1038/modpathol.2014.43. [PubMed]

18. van de Nes JA, Nelles J, Kreis S, Metz CH, Hager T, Lohmann DR, Zeschnigk M. Comparing the Prognostic Value of BAP1 Mutation Pattern, Chromosome 3 Status, and BAP1 Immunohistochemistry in Uveal Melanoma. Am J Surg Pathol. 2016; 40: 796-805. https://doi.org/10.1097/ PAS.0000000000000645. [PubMed]

19. da Costa WH, Fares AF, Bezerra SM, Morini MA, de Toledo Benigno LA, Clavijo DA, Fornazieri L, Rocha MM, da Cunha IW, de Cassio Zequi S. Loss of BAP1 expression in metastatic tumor tissue is an event of poor prognosis in patients with metastatic clear cell renal cell carcinoma. Urol Oncol. 2019; 37: 78-85. https://doi.org/10.1016/j. urolonc.2018.10.017. [PubMed]

20. McDonnell KJ, Gallanis GT, Heller KA, Melas M, Idos GE, Culver JO, Martin SE, Peng DH, Gruber SB. A novel BAP1 mutation is associated with melanocytic neoplasms and thyroid cancer. Cancer Genet. 2016; 209: 75-81. https:// doi.org/10.1016/j.cancergen.2015.12.007. [PubMed]
21. Wang A, Papneja A, Hyrcza M, Al-Habeeb A, Ghazarian D. Gene of the month: BAP1. J Clin Pathol. 2016; 69: 750-53. https://doi.org/10.1136/jclinpath-2016-203866. [PubMed]

22. Forest F, Patoir A, Dal Col P, Sulaiman A, Camy F, Laville D, Bayle-Bleuez S, Fournel P, Habougit C. Nuclear grading, BAP1, mesothelin and PD-L1 expression in malignant pleural mesothelioma: prognostic implications. Pathology. 2018; 50: 635-41. https://doi.org/10.1016/j. pathol.2018.05.002. [PubMed]

23. Wang XY, Wang Z, Huang JB, Ren XD, Ye D, Zhu WW, Qin LX. Tissue-specific significance of BAP1 gene mutation in prognostic prediction and molecular taxonomy among different types of cancer. Tumour Biol. 2017; 39: 1010428317699111. https://doi. org/10.1177/1010428317699111. [PubMed]

24. Qin J, Zhou Z, Chen W, Wang C, Zhang H, Ge G, Shao M, You D, Fan Z, Xia H, Liu R, Chen C. BAP1 promotes breast cancer cell proliferation and metastasis by deubiquitinating KLF5. Nat Commun. 2015; 6: 8471. https://doi.org/10.1038/ncomms9471. [PubMed]

25. Asada S, Goyama S, Inoue D, Shikata S, Takeda R, Fukushima T, Yonezawa T, Fujino T, Hayashi Y, Kawabata KC, Fukuyama T, Tanaka Y, Yokoyama A, et al. Mutant ASXL1 cooperates with BAP1 to promote myeloid leukaemogenesis. Nat Commun. 2018; 9: 2733. https://doi. org/10.1038/s41467-018-05085-9. [PubMed]

26. Wang Z, Wang XY, Li J, Zhu WW. Prognostic and Clinicopathological Significance of BAP1 Protein Expression in Different Types of Cancer-A Meta-Analysis. Genet Test Mol Biomarkers. 2018; 22: 115-26. https://doi. org $/ 10.1089 / \mathrm{gtmb} .2017 .0176$. [PubMed]

27. Je EM, Lee SH, Yoo NJ. Somatic mutation of a tumor suppressor gene BAP1 is rare in breast, prostate, gastric and colorectal cancers. APMIS. 2012; 120: 855-56. https://doi. org/10.1111/j.1600-0463.2012.02909.x. [PubMed]

28. Weischenfeldt J, Simon R, Feuerbach L, Schlangen K, Weichenhan D, Minner S, Wuttig D, Warnatz HJ, Stehr H, Rausch T, Jäger N, Gu L, Bogatyrova O, et al. Integrative genomic analyses reveal an androgen-driven somatic alteration landscape in early-onset prostate cancer. Cancer Cell. 2013; 23: 159-70. https://doi.org/10.1016/j. ccr.2013.01.002. [PubMed]

29. Uhlen M, Oksvold P, Fagerberg L, Lundberg E, Jonasson K, Forsberg M, Zwahlen M, Kampf C, Wester K, Hober S, Wernerus H, Björling L, Ponten F. Towards a knowledgebased Human Protein Atlas. Nat Biotechnol. 2010; 28: 1248-50. https://doi.org/10.1038/nbt1210-1248. [PubMed]

30. Arzt L, Quehenberger F, Halbwedl I, Mairinger T, Popper HH. BAP1 protein is a progression factor in malignant pleural mesothelioma. Pathol Oncol Res. 2014; 20: 145-51. https://doi.org/10.1007/s12253-013-9677-2. [PubMed]

31. De Rienzo A, Archer MA, Yeap BY, Dao N, Sciaranghella D, Sideris AC, Zheng Y, Holman AG, Wang YE, Dal Cin PS, Fletcher JA, Rubio R, Croft L, et al. Gender-Specific Molecular and Clinical Features Underlie Malignant Pleural 
Mesothelioma. Cancer Res. 2016; 76: 319-28. https://doi. org/10.1158/0008-5472.CAN-15-0751. [PubMed]

32. McGregor SM, Dunning R, Hyjek E, Vigneswaran W, Husain AN, Krausz T. BAP1 facilitates diagnostic objectivity, classification, and prognostication in malignant pleural mesothelioma. Hum Pathol. 2015; 46: 1670-78. https://doi.org/10.1016/j.humpath.2015.06.024. [PubMed]

33. Singhi AD, Krasinskas AM, Choudry HA, Bartlett DL, Pingpank JF, Zeh HJ, Luvison A, Fuhrer K, Bahary N, Seethala RR, Dacic S. The prognostic significance of BAP1, NF2, and CDKN2A in malignant peritoneal mesothelioma. Mod Pathol. 2016; 29: 14-24. https://doi.org/10.1038/ modpathol.2015.121. [PubMed]

34. Tang J, Xi S, Wang G, Wang B, Yan S, Wu Y, Sang Y, Wu W, Zhang R, Kang T. Prognostic significance of BRCA1associated protein 1 in colorectal cancer. Med Oncol. 2013; 30: 541. https://doi.org/10.1007/s12032-013-0541-8. [PubMed]

35. Yan S, He F, Luo R, Wu H, Huang M, Huang C, Li Y, Zhou Z. Decreased expression of BRCA1-associated protein 1 predicts unfavorable survival in gastric adenocarcinoma. Tumour Biol. 2016; 37: 6125-33. https://doi.org/10.1007/ s13277-015-3983-0. [PubMed]

36. van Essen TH, van Pelt SI, Versluis M, Bronkhorst IH, van Duinen SG, Marinkovic M, Kroes WG, Ruivenkamp CA, Shukla S, de Klein A, Kiliç E, Harbour JW, Luyten GP, et al. Prognostic parameters in uveal melanoma and their association with BAP1 expression. $\mathrm{Br} \mathrm{J}$ Ophthalmol. 2014; 98: 1738-43. https://doi.org/10.1136/ bjophthalmol-2014-305047. [PubMed]

37. Yu H, Pak H, Hammond-Martel I, Ghram M, Rodrigue A, Daou S, Barbour H, Corbeil L, Hébert J, Drobetsky E, Masson JY, Di Noia JM, Affar B. Tumor suppressor and deubiquitinase BAP1 promotes DNA double-strand break repair. Proc Natl Acad Sci U S A. 2014; 111: 285-90. https://doi.org/10.1073/pnas.1309085110. [PubMed]

38. Chen C, Bhalala HV, Vessella RL, Dong JT. KLF5 is frequently deleted and down-regulated but rarely mutated in prostate cancer. Prostate. 2003; 55: 81-88. https://doi. org/10.1002/pros.10205. [PubMed]

39. Nakajima Y, Osakabe A, Waku T, Suzuki T, Akaogi K, Fujimura T, Homma Y, Inoue S, Yanagisawa J. Estrogen Exhibits a Biphasic Effect on Prostate Tumor Growth through the Estrogen Receptor $\beta$-KLF5 Pathway. Mol Cell Biol. 2015; 36: 144-56. https://doi.org/10.1128/ MCB.00625-15. [PubMed]

40. Li X, Zhang B, Wu Q, Ci X, Zhao R, Zhang Z, Xia S, Su D, Chen J, Ma G, Fu L, Dong JT. Interruption of KLF5 acetylation converts its function from tumor suppressor to tumor promoter in prostate cancer cells. Int J Cancer. 2015; 136: 536-46. https://doi.org/10.1002/ijc.29028. [PubMed]

41. Brase JC, Johannes M, Mannsperger H, Fälth M, Metzger J, Kacprzyk LA, Andrasiuk T, Gade S, Meister M, Sirma H, Sauter G, Simon R, Schlomm T, et al. TMPRSS2-ERG -specific transcriptional modulation is associated with prostate cancer biomarkers and TGF- $\beta$ signaling. BMC Cancer. 2011; 11: 507. https://doi.org/10.1186/1471-240711-507. [PubMed]

42. Tomlins SA, Laxman B, Varambally S, Cao X, Yu J, Helgeson BE, Cao Q, Prensner JR, Rubin MA, Shah RB, Mehra R, Chinnaiyan AM. Role of the TMPRSS2-ERG gene fusion in prostate cancer. Neoplasia. 2008; 10: 177-88. https://doi.org/10.1593/neo.07822. [PubMed]

43. Minner S, Enodien M, Sirma H, Luebke AM, Krohn A, Mayer PS, Simon R, Tennstedt P, Müller J, Scholz L, Brase JC, Liu AY, Schlüter H, et al. ERG status is unrelated to PSA recurrence in radically operated prostate cancer in the absence of antihormonal therapy. Clin Cancer Res. 2011; 17: 5878-88. https://doi.org/10.1158/1078-0432.CCR-111251. [PubMed]

44. Fishilevich S, Nudel R, Rappaport N, Hadar R, Plaschkes I, Iny Stein T, Rosen N, Kohn A, Twik M, Safran M, Lancet D, Cohen D. GeneHancer: genome-wide integration of enhancers and target genes in GeneCards. Database (Oxford). 2017; 2017. https://doi.org/10.1093/database/ bax028. [PubMed]

45. Li H, Sekine M, Tung N, Avraham HK. Wild-type BRCA1, but not mutated BRCA1, regulates the expression of the nuclear form of beta-catenin. Mol Cancer Res. 2010; 8: 407-20. https://doi.org/10.1158/1541-7786.MCR-09-0403. [PubMed]

46. Wu L, Zhao JC, Kim J, Jin HJ, Wang CY, Yu J. ERG is a critical regulator of Wnt/LEF1 signaling in prostate cancer. Cancer Res. 2013; 73: 6068-79. https://doi. org/10.1158/0008-5472.CAN-13-0882. [PubMed]

47. Li Y, Kong D, Wang Z, Ahmad A, Bao B, Padhye S, Sarkar FH. Inactivation of AR/TMPRSS2-ERG/Wnt signaling networks attenuates the aggressive behavior of prostate cancer cells. Cancer Prev Res (Phila). 2011; 4: 1495506. https://doi.org/10.1158/1940-6207.CAPR-11-0077. [PubMed]. Erratum in: Editor's Note: Inactivation of AR/ TMPRSS2-ERG/Wnt Signaling Networks Attenuates the Aggressive Behavior of Prostate Cancer Cells. [Cancer Prev Res (Phila). 2018]. https://doi.org/10.1158/1940-6207. CAPR-18-0315. [PubMed]

48. Burdelski C, Bujupi E, Tsourlakis MC, Hube-Magg C, Kluth M, Melling N, Lebok P, Minner S, Koop C, Graefen M, Heinzer H, Wittmer C, Sauter G, et al. Loss of SOX9 Expression Is Associated with PSA Recurrence in ERGPositive and PTEN Deleted Prostate Cancers. PLoS One. 2015; 10: e0128525. https://doi.org/10.1371/journal. pone.0128525. [PubMed]

49. Burdelski C, Kleinhans S, Kluth M, Hube-Magg C, Minner S, Koop C, Graefen M, Heinzer H, Tsourlakis MC, Wilczak W, Marx A, Sauter G, Wittmer C, et al. Reduced AZGP1 expression is an independent predictor of early PSA recurrence and associated with ERG-fusion positive and PTEN deleted prostate cancers. Int J Cancer. 2016; 138: 1199-206. https://doi.org/10.1002/ijc.29860. [PubMed] 
50. Melling N, Harutyunyan L, Hube-Magg C, Kluth M, Simon R, Lebok P, Minner S, Tsourlakis MC, Koop C, Graefen M, Adam M, Haese A, Wittmer C, et al. High-Level HOOK3 Expression Is an Independent Predictor of Poor Prognosis Associated with Genomic Instability in Prostate Cancer. PLoS One. 2015; 10: e0134614. https://doi.org/10.1371/ journal.pone.0134614. [PubMed]

51. Heumann A, Kaya Ö, Burdelski C, Hube-Magg C, Kluth M, Lang DS, Simon R, Beyer B, Thederan I, Sauter G, Izbicki JR, Luebke AM, Hinsch A, et al. Up regulation and nuclear translocation of Y-box binding protein 1 (YB-1) is linked to poor prognosis in ERG-negative prostate cancer. Sci Rep. 2017; 7: 2056. https://doi.org/10.1038/s41598-017-02279-x. [PubMed]. Erratum in: Author Correction: Up regulation and nuclear translocation of Y-box binding protein 1 (YB-1) is linked to poor prognosis in ERG-negative prostate cancer. [Sci Rep. 2018]. https://doi.org/10.1038/s41598-018-309759. [PubMed]

52. Burdelski C, Dieckmann T, Heumann A, Hube-Magg C, Kluth M, Beyer B, Steuber T, Pompe R, Graefen M, Simon R, Minner S, Tsourlakis MC, Koop C, et al. p16 upregulation is linked to poor prognosis in ERG negative prostate cancer. Tumour Biol. 2016; 37: 12655-63. https:// doi.org/10.1007/s13277-016-5167-y. [PubMed]

53. Heumann A, Heinemann N, Hube-Magg C, Lang DS, Grupp K, Kluth M, Minner S, Möller-Koop C, Graefen M, Heinzer H, Tsourlakis MC, Wilczak W, Wittmer C, et al. High BCAR1 expression is associated with early PSA recurrence in ERG negative prostate cancer. BMC Cancer. 2018; 18: 37. https://doi.org/10.1186/s12885-017-3956-3. [PubMed]

54. Mori T, Sumii M, Fujishima F, Ueno K, Emi M, Nagasaki M, Ishioka C, Chiba N. Somatic alteration and depleted nuclear expression of BAP1 in human esophageal squamous cell carcinoma. Cancer Sci. 2015; 106: 1118-29. https://doi. org/10.1111/cas.12722. [PubMed]

55. Machida YJ, Machida Y, Vashisht AA, Wohlschlegel JA, Dutta A. The deubiquitinating enzyme BAP1 regulates cell growth via interaction with HCF-1. J Biol Chem. 2009; 284: 34179-88. https://doi.org/10.1074/jbc.M109.046755. [PubMed]

56. Eletr ZM, Wilkinson KD. An emerging model for BAP1's role in regulating cell cycle progression. Cell Biochem Biophys. 2011; 60: 3-11. https://doi.org/10.1007/s12013011-9184-6. [PubMed]

57. Sauter G, Clauditz T, Steurer S, Wittmer C, Büscheck F, Krech T, Lutz F, Lennartz M, Harms L, Lawrenz L, MöllerKoop C, Simon R, Jacobsen F, et al. Integrating Tertiary Gleason 5 Patterns into Quantitative Gleason Grading in Prostate Biopsies and Prostatectomy Specimens. Eur Urol. 2018; 73: 674-83. https://doi.org/10.1016/j. eururo.2017.01.015. [PubMed]

58. Sauter G, Steurer S, Clauditz TS, Krech T, Wittmer C, Lutz F, Lennartz M, Janssen T, Hakimi N, Simon R, von Petersdorff-Campen M, Jacobsen F, von Loga K, et al.
Clinical Utility of Quantitative Gleason Grading in Prostate Biopsies and Prostatectomy Specimens. Eur Urol. 2016; 69: 592-98. https://doi.org/10.1016/j.eururo.2015.10.029. [PubMed]

59. Schlomm T, Iwers L, Kirstein P, Jessen B, Köllermann J, Minner S, Passow-Drolet A, Mirlacher M, Milde-Langosch K, Graefen M, Haese A, Steuber T, Simon R, et al. Clinical significance of $\mathrm{p} 53$ alterations in surgically treated prostate cancers. Mod Pathol. 2008; 21: 1371-78. https://doi. org/10.1038/modpathol.2008.104. [PubMed]

60. Kononen J, Bubendorf L, Kallioniemi A, Bärlund M, Schraml P, Leighton S, Torhorst J, Mihatsch MJ, Sauter G, Kallioniemi OP. Tissue microarrays for high-throughput molecular profiling of tumor specimens. Nat Med. 1998; 4: 844-47. https://doi.org/10.1038/nm0798-844. [PubMed]

61. Minner S, Jessen B, Stiedenroth L, Burandt E, Köllermann J, Mirlacher M, Erbersdobler A, Eichelberg C, Fisch M, Brümmendorf TH, Bokemeyer C, Simon R, Steuber T, et al. Low level HER2 overexpression is associated with rapid tumor cell proliferation and poor prognosis in prostate cancer. Clin Cancer Res. 2010; 16: 1553-60. https://doi. org/10.1158/1078-0432.CCR-09-2546. [PubMed]

62. Burkhardt L, Fuchs S, Krohn A, Masser S, Mader M, Kluth M, Bachmann F, Huland H, Steuber T, Graefen M, Schlomm T, Minner S, Sauter G, et al. CHD1 is a $5 \mathrm{q} 21$ tumor suppressor required for ERG rearrangement in prostate cancer. Cancer Res. 2013; 73: 2795-805. https:// doi.org/10.1158/0008-5472.CAN-12-1342. [PubMed]

63. Kluth M, Hesse J, Heinl A, Krohn A, Steurer S, Sirma H, Simon R, Mayer PS, Schumacher U, Grupp K, Izbicki JR, Pantel K, Dikomey E, et al. Genomic deletion of MAP3K7 at $6 \mathrm{q} 12-22$ is associated with early PSA recurrence in prostate cancer and absence of TMPRSS2:ERG fusions. Mod Pathol. 2013; 26: 975-83. https://doi.org/10.1038/ modpathol.2012.236. [PubMed]

64. Krohn A, Diedler T, Burkhardt L, Mayer PS, De Silva C, Meyer-Kornblum M, Kötschau D, Tennstedt P, Huang J, Gerhäuser C, Mader M, Kurtz S, Sirma H, et al. Genomic deletion of PTEN is associated with tumor progression and early PSA recurrence in ERG fusion-positive and fusionnegative prostate cancer. Am J Pathol. 2012; 181: 401-12. https://doi.org/10.1016/j.ajpath.2012.04.026. [PubMed]

65. Krohn A, Seidel A, Burkhardt L, Bachmann F, Mader M, Grupp K, Eichenauer T, Becker A, Adam M, Graefen M, Huland H, Kurtz S, Steurer S, et al. Recurrent deletion of 3 p13 targets multiple tumour suppressor genes and defines a distinct subgroup of aggressive ERG fusion-positive prostate cancers. J Pathol. 2013; 231: 130-41. https://doi. org/10.1002/path.4223. [PubMed]

66. Uhlen M, Zhang C, Lee S, Sjöstedt E, Fagerberg L, Bidkhori G, Benfeitas R, Arif M, Liu Z, Edfors F, Sanli K, von Feilitzen K, Oksvold P, et al. A pathology atlas of the human cancer transcriptome. Science. 2017; 357. https:// doi.org/10.1126/science.aan2507. [PubMed] 